\title{
Influence of different nanoparticles embedded in crystalline carbon monoxide matrix on heat transfer in the nanocomposite
}

\author{
R.V. Nikonkov, P. Stachowiak, and A. Jeżowski \\ Institute for Low Temperature and Structure Research, Polish Academy of Sciences, \\ PN 1410, 50-950 Wroclaw, Poland \\ E-mail: r.nikonkov@intibs.pl
}

Received October 24, 2018

\begin{abstract}
The preliminary results of investigations of heat transfer in nanocomposites consisting of nanoparticles randomly distributed in solid carbon monoxide matrix are presented. In the experiment the thermal conductivity coefficient dependence on temperature for CO crystal with silica and palladium nanoparticles of different size embedded in the crystal structure was determined over the temperature range $2.2-35 \mathrm{~K}$ by steady-state heat flow method. The results of the measurements were analyzed within the frame of relaxation time approximation. The analysis shows that lowering of the thermal conductivity of the nanocomposites relative to pure carbon monoxide crystal observed for both types of the investigated nanoparticles, palladium and silica, is caused mostly by scattering of phonons by boundaries of the nanoparticles. Additionally, the presence of the nanoinclusions promotes higher density of dislocations and influences the matrix lattice dynamics.
\end{abstract}

Keywords: nanocomposite, thermal conductivity, phonon relaxation.

\section{Introduction}

For the recent two decades nanosize and nanostructured objects are focus of tremendous scientific interest. The reason for the interest is twofold: application motivated and purely cognitive. The nanoobjects usually show very different physical properties from those observed for their macroscopic counterparts. Some of the new properties make them successfully utilizable in designing new devices or enhancing parameters of already produced ones. Since prevailing majority of the devices work at ambient or higher temperatures, the application motivated investigations of the properties of the nanostructures are mostly carried out in this temperature region, see, e.g., [1-3]. The interest towards the nanosize and nanostructured objects motivated by scientific curiosity is directly related to their exceptional physical properties and the investigations are carried out in wider temperature range. On the wave of the nano-boom a lot of theoretical works which try to describe and explain physical phenomena in the nano-world have been done. Some of them are devoted to analysis of vibrations of a crystalline lattice in which nanosize particles were embedded. It turned out, for example, that the effect of interaction of the lattice vibrations with an individual nanoparticle strongly depends on the shape of the nanoparticle, its material and the ratio of the linear dimensions to the wave length [4-6]. Also the presence of numerous nanoparticles in a crystalline medium and hence effects of multiple or dependent (correlated) elastic scattering of phonons by the nanoparticles may affect the velocity and density of state of phonons as well as influences the mean free path of phonons in not a trivial way [7]. Additionally, the effects of both multiple and dependent scattering increase with increasing volume fraction of nanoparticles [7]. The mentioned above as well as possibly other effects should influence, among other physical properties, the heat transfer in a crystal with nanoparticles embedded in its structure. In spite of numerous investigations of nanoscale transport related problems, see, e.g., [8] and references therein, the problem of interaction of crystalline matrix phonons with foreign inclusions featuring linear parameters comparable to the phonon wave length, remains far from being understood.

In the current paper we present our preliminary results of experimental investigations of the thermal conductivity of model nanocomposites obtained from nanoparticles of silica and palladium embedded in the crystalline matrix of carbon monoxide. In our experiment the nanoparticles embedded in the matrix made up relatively high fraction of 
the volume of the sample. The experiment was carried out on a number of samples containing nanoparticles of different mean linear dimensions. The choice of the nanocomposite constituents was dictated by relative simplicity both of the carbon monoxide matrix and the $\mathrm{SiO}_{2}$ and $\mathrm{Pd}$ nanopowders. Here, it also should be emphasized that solid CO, belonging to the so-called $\mathrm{N}_{2}$ type solids, is very well-known dielectric crystal.

At equilibrium vapor pressure solid CO appears, depending on the temperature, in one of two structural phases. In the temperature range $61.57-68.09 \mathrm{~K}$ the CO crystal shows a structure in which the linear molecules precess over their mass centers located in an hcp lattice nodes. This is the so-called $\beta$-phase of the crystal. At $61.57 \mathrm{~K}$ the crystal undergoes a structural phase transition: below this temperature it exists in orientationally-ordered fcc structure, known as the $\alpha$-phase. The axes of the molecules are oriented along space diagonals of the elementary cubic cell. Due to the asymmetry of CO molecule, the molecules are displaced a little from the regular lattice positions. This structure belongs to the space group $P 2{ }_{1} 3$ [9]. Despite numerous theoretical propositions [9], an existence of a lowtemperature phase of long-range ordering of carbon monoxide dipoles in the $\alpha$-phase was not confirmed. To the contrary, almost all experiments carried out so far have indicated disordering of the molecules down to temperatures below $1 \mathrm{~K}$. Such a glassy state in the dipole subsystem of orientationally ordered phase of the CO crystal is also seen in the thermal conductivity of the crystal [10].

\section{Experiment}

In our experiment the thermal conductivity of cryocrystal nanocomposites was determined by steady-state heat flow method in the temperature range from 2.2 to $35 \mathrm{~K}$. The methodology of the measurement and its technical aspect have been described in details in our previous paper [11].

The central part of the experimental setup was an ampoule made from glass tube of an inner diameter of $6 \mathrm{~mm}$, a wall thickness of $1 \mathrm{~mm}$ and a length of $50 \mathrm{~mm}$. To the ends of the tube two caps made of copper were fixed with epoxy and two germanium resistance thermometers spaced $10 \mathrm{~mm}$ from each other were glued to the cell cylindrical wall. The lower one was mounted $10 \mathrm{~mm}$ above the bottom of the ampoule. To the top cap an electric gradient heater was attached. Through the cap a thin-wall stainless steel capillary ran. The capillary allowed to pump out the cell or fill it with carbon monoxide gas and thermal exchange gaseous helium. During the experiment the bottom cap rested in a copper base of controlled temperature.

For obtaining the nanocomposite samples, gaseous carbon monoxide of 99.999\% purity and amorphous silica oxide as well as amorphous palladium nanoparticles of different size were used. The $\mathrm{SiO}_{2}$ nanopowders featured nanoparticles of linear dimension of about 5, 18, 42, $162 \mathrm{~nm}$ while the Pd nanoparticles - 6, 8, 10, 12, 18 and $24 \mathrm{~nm}$.
The nanoparticle volume fraction in the investigated samples (the ratio of the volume taken by the nanoparticle to the volume of the sample) was approximately $7 \%$ for $\mathrm{CO}-\mathrm{SiO}_{2}$ and $14 \%$ for CO-Pd nanocomposites, regardless of the linear dimension of the nanoparticles. The volume fraction was determined by precise weighting of the nanopowder filling the volume of the ampoule.

For each sample the powder was placed inside the cell to fully fill the tube after the bottom cap was fixed to the ampoule. Then the upper cap was also glued and the assembled cell was installed in the measuring chamber of the cryostat. At the beginning of the experiment the temperature of the cell was lowered to a little bit above the triple point temperature of carbon monoxide and the gas was let to the cell, whereupon the condensation to its liquid phase began. During the condensation the temperature of the upper part of the cell was maintained a few Kelvins higher than the temperature of the bottom so that the liquid gradually filled the cell from its bottom to the top. Finally, the temperature of the bottom of the ampoule was slowly lowered - the liquid solidified forming carbon monoxide $\mathrm{SiO}_{2}$ or carbon monoxide Pd cryocrystal nanocomposite. Cooling rate during the crystal growth was $3 \mathrm{~K} / \mathrm{h}$. After crystallization the nanocomposite was cooled down to the temperature of the thermal conductivity measurement at the cooling rate of $6 \mathrm{~K} / \mathrm{h}$.

In the process of determination of the thermal conductivity two distorting factors were taken into account: (i) the parasitic temperature gradient being a result of the heat radiation due to the temperature mismatch of the LHe thermal shield of the measuring cell and the sample and (ii) the heat transported by the cell glass wall. To determine the first one, the measurements of the parasitic temperature gradient was carried out at various temperatures for each of the samples. As for the second one, the measurement of the dependence of the thermal conductivity coefficient of empty cell was performed in a separate experiment.

The random error of the thermal conductivity measurement at low temperatures did not exceed $1.5 \%$, whereas above $20 \mathrm{~K}$ it increased to $3 \%$, mostly due to effects connected with spurious heat leaks. The systematic error did not exceed $3 \%$.

\section{Results}

Figures 1 and 3 show our measurement results of the dependences of the thermal conductivity coefficient $k$ for carbon monoxide based nanocomposites with palladium spherical nano-admixtures and with silica nanoparticles of different size on temperature. Both of the obtained families of the temperature dependences of $k$ dispaly the shape typical for a dielectric crystal. Generally, impurities cause a decreasing of total thermal conductivity of the investigated nanocomposites when compared to pure crystal of carbon monoxid [10]. 


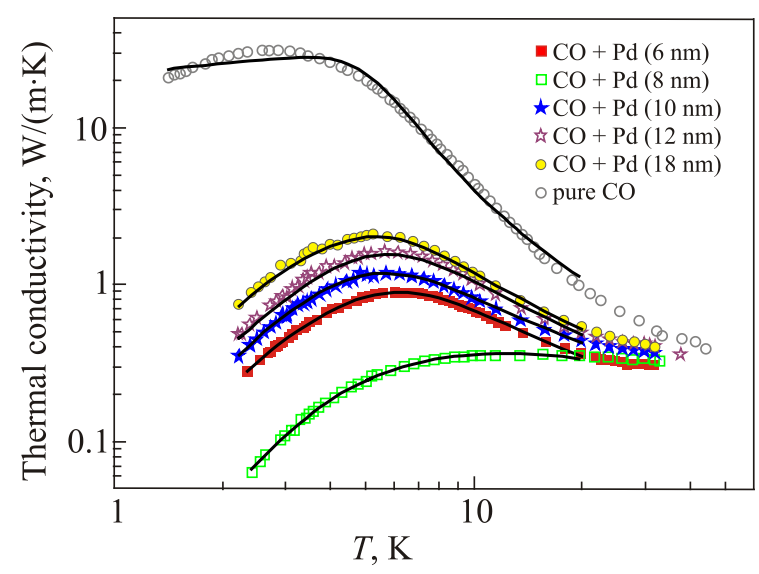

Fig. 1. (Color online) Temperature dependences of thermal conductivity of carbon monoxide nanocomposite with palladium nanoparticles of different linear dimensions: $6 \mathrm{~nm}(\boldsymbol{\square}), 8 \mathrm{~nm}(\square)$, $10 \mathrm{~nm}(\star), 12 \mathrm{~nm}(\boldsymbol{\xi})$ and $18 \mathrm{~nm}(\mathbf{O})$. For the comparison purpose the data for pure CO were also shown $(O)$ [10]. Solid lines are approximations of the experimental data with the expression (10).

The thermal conductivity of the nanocomposites depends on the nanoparticles size and the dependence is not monotonic. Initially the thermal conductivity decreases with increasing nano-spheres diameter and after achieving certain "critical" particles size, for which the phonon scattering reaches its maximum (and the thermal conductivity reaches its minimum), further increasing of particles size causes an increase of samples thermal conductivity, see Figs. 2 and 4. Here it should be noticed that for the samples with $\mathrm{SiO}_{2}$ nanoparticles the size-effect is clear however not as prominent as for the CO-Pd nanostructure.

In all cases the thermal conductivity at higher temperatures $(T>20 \mathrm{~K})$ aspire to the same value, the value of the thermal conductivity of pure CO crystal.

Taking into account that the characteristics of the used nanoadmixtures (the type of the material, the linear dimen-

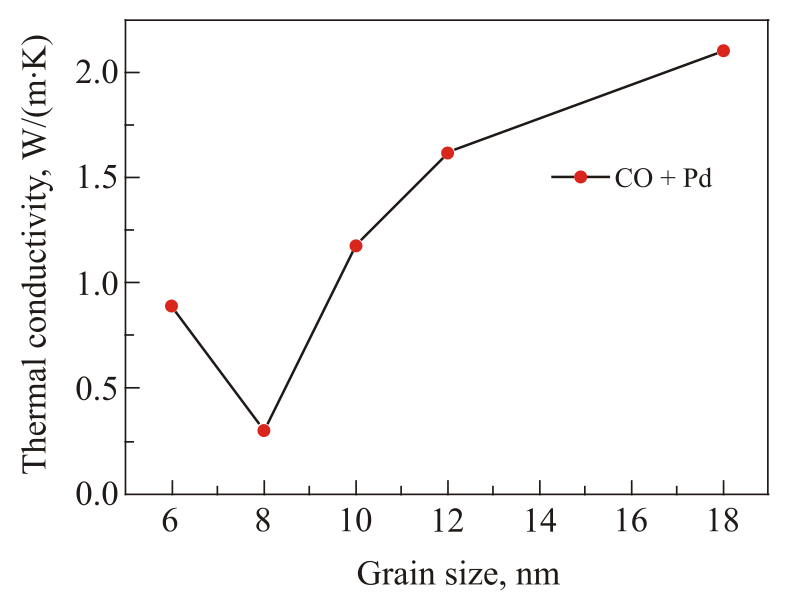

Fig. 2. The thermal conductivity (at the maximum of the thermal conductivity curve) of carbon monoxide based nanocomposite as a function of palladium nanoparticle size.

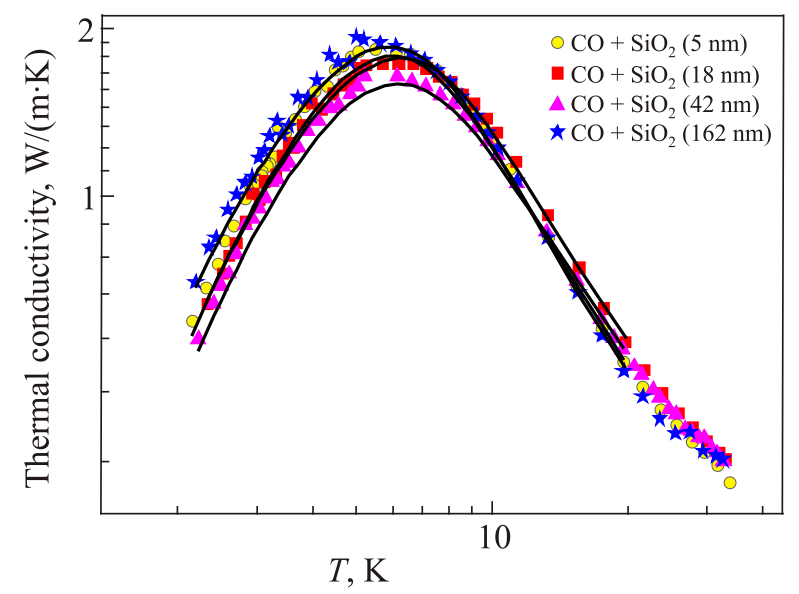

Fig. 3. (Color online) Thermal conductivity of carbon monoxide nanocomposite with $\mathrm{SiO}_{2}$ nanoparticles of different linear dimensions: $5 \mathrm{~nm}(\boldsymbol{\bullet}), 18 \mathrm{~nm}(\boldsymbol{\square}), 42 \mathrm{~nm}(\boldsymbol{\Delta}), 162 \mathrm{~nm}(\star)$.

sions and the volume fraction) are strongly different from each other and that their effect on the total thermal conductivity of the samples is similar (compare Figs. 2 and 4), one can assume, that the material of the sample matrix gives the decisive contribution to the thermal conductivity. The impurities cause only some extra effects in the matrix.

Therefore, the results of the measurements were analyzed using the Callaway method [12]. In this approach each mechanism of elastic scattering of phonons is represented by its characteristic relaxation time. The thermal conductivity of a dielectric crystal can be written as a sum

$$
k=k_{1}+k_{2},
$$

where

$$
k_{1}=\frac{k_{B}}{2 \pi^{2} v}\left(\frac{k_{B}}{\hbar}\right)^{3} T^{3} \int_{0}^{\theta / T} \frac{\tau_{C} x^{4} \mathrm{e}^{x}}{\left(\mathrm{e}^{x}-1\right)^{2}} d x
$$

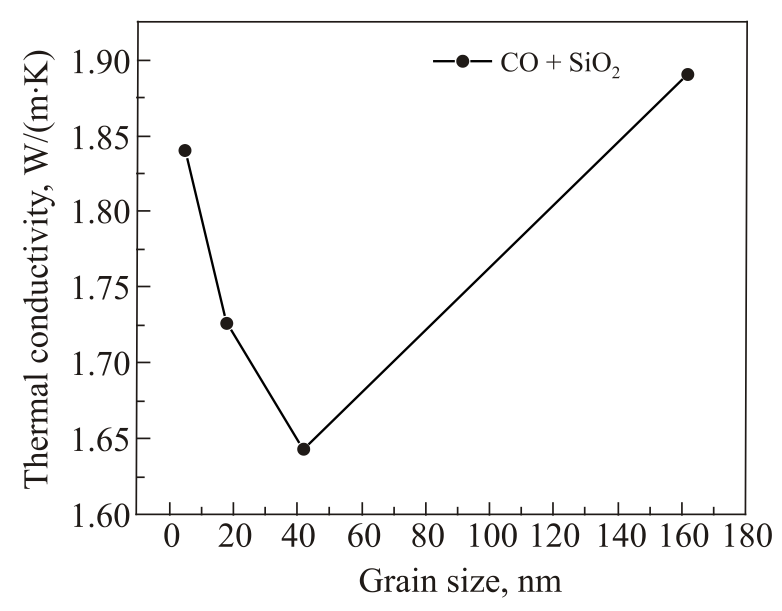

Fig. 4. The thermal conductivity (at the maximum of the thermal conductivity curve) of CO-based nanocomposite as a function of silica nano-inclusions size. 
and

$$
k_{2}=\frac{k_{B}}{2 \pi^{2} v}\left(\frac{k_{B}}{\hbar}\right)^{3} T^{3} \frac{\left(\int_{0}^{\theta / T} \frac{\tau_{C}}{\tau_{n}} \frac{x^{4} \mathrm{e}^{x}}{\left(\mathrm{e}^{x}-1\right)^{2}} d x\right)^{2}}{\int_{0}^{\theta / T} \frac{\tau_{C}}{\tau_{n} \tau_{r}} \frac{x^{4} \mathrm{e}^{x}}{\left(\mathrm{e}^{x}-1\right)^{2}} d x},
$$

where $G=k_{B}^{4} / 2 \pi^{2} v \hbar^{3}, x=\hbar \omega / k_{B} T ; \theta=103.3 \mathrm{~K}$ is Debye temperature of carbon monoxide crystal, $\tau_{i}$ is relaxation time of phonon scattering, $v=\left(\left(v_{l}^{-3}+2 v_{t}^{-3}\right) / 3\right)^{-1 / 3}=1225.5 \mathrm{~ms}^{-1}$ is phonon propagation velocity averaged over longitudinal $v_{l}$ and transversal $v_{t}$ polarizations [9], and $\omega$ is phonon frequency.

Assuming additivity of the effects of scattering, the total relaxation rate $\tau_{C}^{-1}$ may be written down as a sum of the relaxation rates of the resistive $\tau_{r}^{-1}$ and normal $\tau_{n}^{-1}$ processes:

$$
\tau_{C}^{-1}=\tau_{r}^{-1}+\tau_{n}^{-1}
$$

where

$$
\tau_{r}^{-1}=\tau_{b}^{-1}+\tau_{p}^{-1}+\tau_{d}^{-1}+\tau_{U}^{-1}
$$

and the quantities

$$
\begin{gathered}
\tau_{b}^{-1}=a_{b}, \\
\tau_{p}^{-1}=a_{p} x^{4} T^{4}, \\
\tau_{d}^{-1}=a_{d} x T, \\
\tau_{U}^{-1}=a_{U 1} x^{2} T^{3} \exp \left[-a_{U 2} / T\right]
\end{gathered}
$$

are relaxation rates of phonon scattering by grain boundaries, point defects, dislocation strain fields and three-phonon U-processes, respectively.

As a matter of fact, normal processes are only significant for the thermal conductivity of crystals of high quality and at low temperatures [13]. Otherwise, the normal processes are much less frequent then other phonon scattering processes and do not contribute noticeably to the dielectric crystal heat transfer. Therefore, for strongly defected crystal, $\tau_{n}^{-1}$ can be neglected and then the Eq. (1) reduces to the so-called expression of Debye:

$$
k=\frac{k_{B}}{2 \pi^{2} v}\left(\frac{k_{B}}{\hbar}\right)^{3} T^{3} \int_{0}^{\theta / T} \frac{\tau_{C} x^{4} \mathrm{e}^{x}}{\left(\mathrm{e}^{x}-1\right)^{2}} d x .
$$

We have fitted the Debye equation, by varying $a_{i}$ parameters of relaxation times (6)-(9), to the experimentally obtained data of the thermal conductivity temperature dependence of the nanocomposites. The results of the best match for samples of solid CO containing palladium nanoparticles were shown in Fig. 1 by solid black lines and the parameters were collected in Table 1 . The same information, displayed in the same way, for the CO crystal with silica nanoparticles embedded in its structure was given in Fig. 3 and Table 2.

Table 1. Best fit phonon relaxation rate parameters obtained by Debye equation for the $\mathrm{CO}$ crystals containing palladium nanoparticles. In the fitting procedure scattering of phonons by crystal grain boundaries $\left(a_{b}\right)$, point defects $\left(a_{p}\right)$, dislocation strain fields $\left(a_{d}\right)$ and by phonons in U-processes $\left(a_{U 1}, a_{U 2}\right)$ were taken into account

\begin{tabular}{c|c|c|c|c|c}
\hline \hline \multirow{2}{*}{ Nanocomposite } & \multicolumn{5}{|c}{ Parameter } \\
\cline { 2 - 6 } & $a_{b}$ & $a_{p}$ & $a_{d}$ & $a_{U 1}$ & $a_{U 2}$ \\
\hline \hline CO+Pd (6 nm) & $5.61 \cdot 10^{8}$ & $1.31 \cdot 10^{4}$ & $2.23 \cdot 10^{6}$ & $1.27 \cdot 10^{7}$ & 19.9 \\
\hline CO+Pd (8 nm) & $3.55 \cdot 10^{9}$ & $1.83 \cdot 10^{4}$ & $1.00 \cdot 10^{6}$ & $6.07 \cdot 10^{6}$ & 6.0 \\
\hline CO+Pd (10 nm) & $3.14 \cdot 10^{8}$ & $1.11 \cdot 10^{4}$ & $1.79 \cdot 10^{7}$ & $1.08 \cdot 10^{7}$ & 18.0 \\
\hline CO+Pd (12 nm) & $3.09 \cdot 10^{8}$ & $1.17 \cdot 10^{4}$ & $2.93 \cdot 10^{6}$ & $1.11 \cdot 10^{7}$ & 21.2 \\
\hline CO+Pd (18 nm) & $1.67 \cdot 10^{8}$ & $1.27 \cdot 10^{4}$ & $3.08 \cdot 10^{5}$ & $9.87 \cdot 10^{6}$ & 21.1 \\
\hline \hline
\end{tabular}

Table 2. Values of the parameters $a_{b}, a_{p}, a_{d}, a_{U 1}, a_{U 2}$ of equation (10), for which the experimentally obtained dependence of the thermal conductivity of the investigated nanocomposites is best approximated

\begin{tabular}{c|c|c|c|c|c}
\hline \hline \multirow{2}{*}{ Nanocomposite } & \multicolumn{5}{|c}{ Parameter } \\
\cline { 2 - 6 } & $a_{b}$ & $a_{p}$ & $a_{d}$ & $a_{U 1}$ & $a_{U 2}$ \\
\hline \hline Pure CO & $2.47 \cdot 10^{4}$ & $3.81 \cdot 10^{4}$ & $1.21 \cdot 10^{4}$ & $7.27 \cdot 10^{6}$ & 32.8 \\
\hline $\mathrm{CO}+\mathrm{SiO}_{2}(5 \mathrm{~nm})$ & $1.88 \cdot 10^{8}$ & $1.78 \cdot 10^{4}$ & $1.82 \cdot 10^{6}$ & $1.91 \cdot 10^{7}$ & 25.6 \\
\hline $\mathrm{CO}+\mathrm{SiO}_{2}(18 \mathrm{~nm})$ & $1.85 \cdot 10^{8}$ & $2.09 \cdot 10^{4}$ & $2.02 \cdot 10^{5}$ & $1.03 \cdot 10^{7}$ & 26.2 \\
\hline $\mathrm{CO}+\mathrm{SiO}_{2}(42 \mathrm{~nm})$ & $2.92 \cdot 10^{8}$ & $2.81 \cdot 10^{4}$ & $2.72 \cdot 10^{6}$ & $1.33 \cdot 10^{7}$ & 24.1 \\
\hline $\mathrm{CO}+\mathrm{SiO}_{2}(162 \mathrm{~nm})$ & $1.81 \cdot 10^{8}$ & $3.54 \cdot 10^{4}$ & $6.35 \cdot 10^{6}$ & $2.05 \cdot 10^{7}$ & 26.6 \\
\hline \hline
\end{tabular}

The solid lines in Figs. 1 and 3 show that the approximation of the experimental data with the applied thermal conductivity model is satisfactory. Therefore one can get some information from the analysis of the numerical values displayed in Tables 1 and 2. First of all, it should be noticed that the effect of introduction of the nanoparticle into the structure of carbon monoxide crystalline matrix on phonon relaxation rates is qualitatively the same for both investigated nano-powders, palladium and silica. The most prominent effect is observed for scattering of phonons by grain boundaries. While for pure CO crystal $\tau_{p}^{-1} \sim 10^{4} \mathrm{~s}^{-1}$, for the nano-powder doped ones $\tau_{b}^{-1} \sim 10^{8} \mathrm{~s}^{-1}$. Such tremendous increase of frequency of phonon scattering in this mechanism should be understood as not caused by structural grain boundaries but rather diffuse scattering of phonons by boundary of the two media: carbon monoxide and palladium or silica. Point defect (Rayleigh) scattering is almost insensitive to the presence of the nanoparticles. This is because the nanoparticles can act as point defect only for long-wave phonons which do not contribute noticeably to the thermal 
conductivity, at least in the investigated temperature region. The significant increase of $a_{d}$ for the nanoparticles doped crystal relatively to the pure solid CO indicates that the presence of the nano-powders promotes creation of dislocations. Finally, the difference of $a_{U 1}$ and $a_{U 2}$ parameters, between those obtain for pure carbon monoxide crystal and the investigated nanocomposites, may be related to the difference of pure and doped matrix lattice dynamics. Since $a_{U 1}$ is considered as a measure of phonon interaction strength [14], the parameter bigger for the nanocomposite testify to higher anharmonicity of the lattice vibration while smaller $a_{U 2}$ (being a measure of mean energy of a phonon taking part in U-process) to lowering of the maximum frequency vibrations of the matrix in such nanocomposites.

In conclusion, nanocomposites built from carbon monoxide crystal with amorphous silica and palladium nanopowders of different size embedded in the crystal structure were obtained and determined their thermal conductivity coefficient dependence on temperature in the temperature range 2.2-35 K. Nano-impurities in the crystal cause a decreasing of total thermal conductivity of investigated nanocomposites compared to the pure crystal of carbon monoxide. Analysis of the experimental results shows that the material of the sample matrix gives the decisive contribution to the thermal conductivity and that the low thermal conductivity of the nanocomposites is caused mostly by scattering of phonons by boundaries of the nanoparticles.

\section{Acknowledgments}

This work was supported by the National Science Centre (Poland) grant nr. UMO-2013/08/M/ST3/00934.

1. N. Mingo, D. Hauser, N.P. Kobayashi, M. Plissonnier, and A. Shakouri, Nano Lett. 9, 711 (2009).

2. P.E. Hopkins, J.C. Duda, C.W. Petz, and J.A. Floro, Phys. Rev. B 84, 035438 (2011).

3. B. Poudel, Q. Hao, Y. Ma, Y. Lan, A. Minnich, B. Yu, X. Yan, D. Wang, A. Muto, D. Vashaee, X. Chen, J. Liu, M.S. Dresselhaus, G. Chen, and Z. Ren, Science 320, 634 (2008).

4. W. Kim and A. Majumdar, J. Appl. Phys. 99, 084306 (2006).

5. L.A. Turk and P.G. Klemens, Phys. Rev. B 9, 4422 (1974).

6. R. Prasher, Int. J. Heat Mass Trans. 48, 4942 (2005).

7. R. Prasher, J. Heat Transf. 128, 627 (2006).

8. D.G. Cahill, P.V. Braun, G. Chen, D.R. Clarke, S. Fan, K.E. Goodson, P. Keblinski, W.P. King, G.D. Mahan, A. Majumdar, H.J. Maris, S.R. Phillpot, E. Pop, and L. Shi, Appl. Phys. Rev. 1, 011305 (2014).

9. V.G. Manzhelii and Yu.A. Freiman, Physics of Cryocrystals, AIP, Woodbury, NY (1997).

10. T. Romanova, P. Stachowiak, and A. Jeżowski, Solid State Comm. 197, 6 (2014).

11. R.V. Nikonkov, P. Stachowiak, T.V. Romanova, A. Jeżowski, and V.V. Sumarokov, Fiz. Nizk. Temp. 41, 625 (2015) [Low Temp. Phys. 41, 492 (2015)].

12. J. Callaway, Phys. Rev. 113, 1046 (1959).
13. R. Berman, Thermal Conduction in Solids, Oxford, Clarendon Press (1976).

14. H.T. Weston and W.B. Daniels, Phys. Rev. B 29, 2709 (1984).

\section{Вплив наночастинок, введених в кристалічну матрицю монооксиду вуглецю, на теплопереніс в нанокомпозиті}

\section{R.V. Nikonkov, P. Stachowiak, A. Jeżowski}

Наведено попередні результати досліджень теплопереносу в нанокомпозитах, які містять наночастинки, що випадково розподілені у твердій матриці монооксиду вуглецю. Методом стаціонарного теплового потоку в температурному інтервалі 2,2-35 К визначено експериментальні залежності коефіцієнта теплопровідності від температури для кристалевого СО, що містить наночастинки оксиду кремнію та паладію різних розмірів. Результати вимірювань проаналізовано в рамках апроксимації часу релаксації. Аналіз показує, що зниження теплопровідності нанокомпозитів щодо чистого кристала монооксиду вуглецю, яке спостерігається для досліджених наночастинок паладію та оксиду кремнію, обумовлено головним чином розсіюванням фононів на границях наночастинок. Крім того, наявність нановключень сприяє більш високій щільності дислокацій і впливає на динаміку гратки матриці.

Ключові слова: нанокомпозит, теплопровідність, фононна релаксація.

\section{Влияние наночастиц, введенных в кристаллическую матрицу монооксида углерода, на теплоперенос в нанокомпозите}

\section{R.V. Nikonkov, P. Stachowiak, A. Jeżowski}

Приведены предварительные результаты исследований теплопереноса в нанокомпозитах, содержащих наночастицы, случайным образом распределенные в твердой матрице монооксида углерода. Методом стационарного теплового потока в температурном интервале 2,2-35 К определены экспериментальные зависимости коэффициента теплопроводности от температуры для кристаллического СО, содержащего внедренные наночастицы оксида кремния и палладия различных размеров. Результаты измерений проанализированы в рамках аппроксимации времени релаксации. Анализ показывает, что понижение теплопроводности нанокомпозитов относительно чистого кристалла монооксида углерода, наблюдаемое для исследуемых наночастиц палладия и оксида кремния, обусловлено главным образом рассеянием фононов на границах наночастиц. Кроме того, наличие нановключений способствует более высокой плотности дислокаций и влияет на динамику решетки матрицы.

Ключевые слова: нанокомпозит, теплопроводность, фононная релаксация. 